2. Ravindranath V, Anandatheerthavarada $H K$ and Shankar SK, NADPH cytochrome P-450 reductase in rat, mouse and human brain. Biochem Pharmacol 39: 1013-1018, 1990.

3. Ravindranath V, Anandatheerthavarada $\mathrm{HK}$ and Shankar SK, Xenobiotic metabolism in human brainpresence and cytochrome $\mathrm{P}-450$ and associated monooxygenases. Brain Res 496: 331-335, 1989.

4. Anandatheerthavarada HK, Shankar SK and Ravindranath V, Rat brain cytochromes P-450: catalytic, immunochemical properties and inducibility of multiple forms. Brain Res 536: 339-343, 1990.

5. Ziegler DM, Microsomal flavin-containing monooxygenase: Oxygenation of nucleophilic nitrogen and sulpher compounds. In: Enzymatic Basis of Detoxification (Ed. Jakoby WB), Vol. I, pp. 201-207. Academic Press, New York, 1980.

6. Ziegler DM, Flavin-containing monooxygenases: catalytic mechanism and substrate specificities. Drug Metab Rev 19: 1-32, 1988.

7. Ravindranath $\mathrm{V}$ and Anandatheerthavarada HK, Preparation of brain microsomes with cytochrome P450 activity using calcium aggregation method. Anal
Biochem 187: 310-313, 1990.

8. Cavagnaro J, Rauckman EJ and Rosen GM, Estimation of FAD-monooxygenase in microsomal preparations. Anal Biochem 118: 204-211, 1981.

9. Bradford MM, A rapid and sensitive method for the quantitation of microgram quantities of protein utilizing the principle of dye binding. Anal Biochem 72: 248254,1976 .

10. Jeffcoate CRE, Gaylor JL and Calabrese RL, Ligand interaction with cytochrome P-450: binding of primary amines. Biochemistry 8: 3455-3465, 1969.

11. Cashman JR and Hanzlik RP, Microsomal oxidation of thiobenzamide: a photometric assay for FMO. Biochem Biophys Res Commun 98: 147-153, 1981.

12. Tynes RE and Hodgson E, Catalytic activity and substrate specificity of the flavin-containing monooxygenase in microsomal systems: characterization of the hepatic, pulmonary and renal enzymes of the mouse, rabbit and rat. Arch Biochem Biophys 240: 7793, 1985 .

13. Duffel MW and Gillespie SG, Microsomal flavincontaining monooxygenase activity in rat corpus striatum. J Neurochem 42: 1350-1353, 1984.

\title{
Differential expression and ciprofibrate induction of hepatic UDP- glucuronyltransferases for thyroxine and triiodothyronine in Fischer rats
}

\author{
(Received 26 October 1990; accepted 9 March 1991)
}

\begin{abstract}
The possible implication of thyroid hormone in the hypolipidaemic action of phenoxyisobutyrate (fibrate) drugs has been suggested by the finding that clofibrate stimulates liver mitochondrial $\alpha$-glycerophosphate dehydrogenase activity, a classical thyromimetic response [1]. Observations of a drug-induced increase in hepatic uptake of thyroxine $\left(\mathrm{T}_{4}{ }^{*}\right)$ have been interpreted in support of this view [1]. Although clofibrate treatment raises the plasma level of $\mathrm{T}_{4}$-binding proteins, competitive displacement of $\mathrm{T}_{4}$ from these sites by the drug augments the plasma free $T_{4}$ fraction with a resultant shift into the tissues [1-3]. However, it is questionable if this results in a thyrotoxic state of the tissues, since the plasma free $\mathrm{T}_{4}$ concentration during chronic clofibrate treatment is normal $[2,3]$.

Enzymatic deiodination determines the bioactivity of $T_{4}$ through conversion to the active hormone $3,3^{\prime}, 5-$ triiodothyronine $\left(\mathrm{T}_{3}\right)$ or to the inactive isomer $3,3^{\prime}, 5^{\prime}$ triiodothyronine (reverse $T_{3}$ ) [4]. Both metabolites are also further metabolized by deiodination. Other important pathways in the metabolism of thyroid hormone involve the conjugation of the phenolic hydroxyl group with glucuronic acid or sulfate [4]. The sulfate conjugates are
\end{abstract}

* Abbreviations: DTT, dithiothreitol; HA, high activity; LA, low activity; MC, 3-methylcholanthrene; PNP, $p$ nitrophenyl; PCB, polychlorobiphenyl; TCDD, 2,3,7,8tetrachlorodibenzo-p-dioxin; $\mathrm{T}_{3}, 3,3^{\prime}, 5$-triiodothyronine; $\mathrm{T}_{4}$, thyroxine; TBG, $\mathrm{T}_{4}$-binding globulin; UDPGA, UDPglucuronic acid; UDPGT, UDP-glucuronyltransferase. rapidly degraded in the liver by the type I iodothyronine deiodinase, and $T_{4}$ and $T_{3}$ are excreted in rat bile largely as glucuronides [4]. In contrast to an early report [5], clofibrate has been shown to stimulate the biliary clearance of $T_{4}[6]$. Not only clofibrate [6,7] but also fenofibrate [7], the fibrate derivative nafenopin [8] and ciprofibrate [9] accelerate the metabolic clearance of $\mathrm{T}_{4}$ in rats. It has been demonstrated that nafenopin and ciprofibrate strongly increase the faecal clearance of $\mathrm{T}_{4}$, whereas the urinary (deiodinative) clearance of $T_{4}$ is not affected [8] or even inhibited [9]. Little effect of these drugs was noted on the metabolic clearance of $T_{3}[8,9]$. Fibrates are well-known inducers of bilirubin UDP-glucuronyltransferase (UDPGT) in the liver $[10,11]$. In this study we examined the effects of ciprofibrate administration to rats on hepatic $T_{4}$ and $T_{3}$ UDPGT activities. In order to gain more insight into the isozymes responsible for the glucuronidation of $T_{4}$ and $T_{3}$ we investigated, in parallel, the effects of ciprofibrate on p-nitrophenol (PNP) and androsterone UDPGT activities.

\section{Materials and Methods}

L-T $T_{4}, \mathrm{~L}-\mathrm{T}_{3}$, PNP and Brij 56 were obtained from the Sigma Chemical Co. (St Louis, MO, U.S.A.), $\left[{ }^{125} \mathrm{I}\right] \mathrm{T}_{4}$ $(1500 \mu \mathrm{Ci} / \mu \mathrm{g})$ and $\left[{ }^{125} \mathrm{I}\right] \mathrm{T}_{3}(2800 \mu \mathrm{Ci} / \mu \mathrm{g})$ from Amersham (Amersham, U.K.), androsterone from Steraloids (Wilton, NH, U.S.A. $),\left[{ }^{3} \mathrm{H}\right]$ androsterone $(116 \mu \mathrm{Ci} / \mu \mathrm{g})$ from New England Nuclear (Boston, MA, U.S.A.) and UDPglucuronic acid (UDPGA) from Boehringer (Mannheim, F.R.G.). Fischer 344 rats were obtained from Charles River (Margate, U.K.) and Wistar rats from Harlan 
Sprague Dawley (Zeist, The Netherlands)

Male Fischer 344 rats were treated orally for 14 days with ciprofibrate $(30 \mathrm{mg} / \mathrm{kg}$ body wt per day) or with vehicle. Twenty-four $\mathrm{hr}$ after the last dose blood was taken for measurement of serum $T_{4}$ and $T_{3}$ concentrations. Livers were isolated, perfused with saline and homogenized in $0.25 \mathrm{M}$ sucrose, $50 \mathrm{mM}$ Tris- $\mathrm{HCl}(\mathrm{pH} 7.4)$ and $1 \mathrm{mM}$ DTT $(25 \% \mathrm{w} / \mathrm{w})$. Homogenates were centrifuged for $40 \mathrm{~min}$ at $9000 \mathrm{~g}$ and the supernatants for $60 \mathrm{~min}$ at $100,000 \mathrm{~g}$. The resulting microsomal pellets were suspended in $0.25 \mathrm{M}$ sucrose, $50 \mathrm{mM}$ Tris- $\mathrm{HCl}(\mathrm{pH} 7.4)$ and $1 \mathrm{mMDTT}$ at a protein concentration of $10-20 \mathrm{mg} / \mathrm{mL}$, and aliquots were stored at $-70^{\circ}$ until further analysis. Liver microsomes were prepared similarly from untreated male Wistar rats.

UDPGT activities were determined in duplicate at $37^{\circ}$ in $200 \mu \mathrm{L} \quad 50-100 \mathrm{mM}$ Tris-HCl (pH 7.4-7.8), 5$10 \mathrm{mM} \mathrm{MgCl}_{2}$ and $0.05 \%$ Brij 56 , with or without (blanks) $5 \mathrm{mM}$ UDPGA as cofactor [10]. $\mathrm{T}_{4}$ and $\mathrm{T}_{3}$ UDPGT activities were assayed by incubation of $1 \mu \mathrm{M}(\approx 0.1 \mu \mathrm{Ci})$ $\left.{ }^{[25} \mathrm{I}\right] \mathrm{T}_{4}$ or $\left[{ }^{125} \mathrm{I}\right] \mathrm{T}_{3}$ for $1 \mathrm{hr}$ with $1 \mathrm{mg}$ microsomal protein/ $\mathrm{mL}$. Reactions were stopped by addition of $200 \mu \mathrm{L}$ ice-cold methanol and analysed by Sephadex LH-20 chromatography of the supernatants [12]. PNP UDPGT activity was assayed by incubation of $1 \mathrm{mM}$ PNP for $30 \mathrm{~min}$ with $0.5 \mathrm{mg}$ microsomal protein $/ \mathrm{mL}$. Reactions were stopped by addition of $3.8 \mathrm{~mL} 0.1 \mathrm{M} \mathrm{NaOH}$ and analysed by measuring the decrease in absorbance at $407 \mathrm{~nm}$ [13]. Androsterone UDPGT activity was assayed by incubation of 10 or $100 \mu \mathrm{M}(\approx 0.1 \mu \mathrm{Ci})\left[{ }^{3} \mathrm{H}\right]$ androsterone for $30 \mathrm{~min}$ with $0.25-0.5 \mathrm{mg}$ microsomal protein $/ \mathrm{mL}$. Reactions were stopped by the addition of $2 \mathrm{~mL}$ ice-cold water and analysed by liquid scintillation counting after extraction of remaining substrate with ethyl acetate [14].

UDPGT activities in untreated rats of different strains were compared using analysis of variance followed by a test of least significant differences. The significance of differences in UDPGT activities between control and ciprofibrate-treated Fischer rats was determined using Student's $t$-test.

\section{Results and Discussion}

Treatment of Fischer rats with ciprofibrate produced a pronounced decrease in serum $\mathrm{T}_{4}$ from $38.4 \pm 4.5(\mathrm{SD})$ to $7.7 \pm 1.1 \mathrm{nmol} / \mathrm{L} \quad(\mathrm{P}<0.001)$, while serum $\mathrm{T}_{3}$ was not changed $(0.55 \pm 0.15 \mathrm{nmol} / \mathrm{L}$ in controls and $0.55 \pm 0.08 \mathrm{nmol} / \mathrm{L}$ in ciprofibrate-treated rats). Analysis of the liver microsomes from these animals showed that ciprofibrate induced an approximately 3 -fold increase in $T_{4}$ UDPGT activity and a $57 \%$ increase in $T_{3}$ UDPGT activity, whereas UDPGT activities for PNP and androsterone were decreased by $45 \%$ and $22 \%$, respectively (Table 1 ).

We have recently observed a discontinuous variation in the $T_{3}$ UDPGT activity of Wistar rat liver microsomes which exactly matched the genetic heterogeneity of androsterone UDPGT in this rat strain [15]. The latter has been documented extensively by Matsui and Hakozaki [14], who showed that the difference between Wistar rats with low activity (LA) and those with high activity (HA) of androsterone UDPGT represents an autosomal recessive trait. It has recently been demonstrated that the defect is caused by a deletion mutation in the gene coding for this UDPGT [10]. $\mathrm{T}_{4}$ glucuronidation is only slightly lower in LA compared with HA rats, and PNP UDPGT activity is not different between these phenotypes [15].

Figure 1 shows the comparison between the UDPGT activities for $T_{4}, T_{3}$ and androsterone in liver microsomes from untreated Fischer and Wistar rats. Hepatic PNP UDPGT activity in normal Fischer rats is about one-third of that in Wistar rats $(25.6 \pm 2.4$ (SD) vs $74.1 \pm 6.0 \mathrm{nmol} /$ $\mathrm{min} / \mathrm{mg}$ protein). Androsterone UDPGT activity in Wistar rat livers shows the well-established heterogeneity; under the assay conditions used, enzyme activity in LA microsomes is less than $10 \%$ of that in HA microsomes. Liver
Table 1. Effects of treatment of Fischer rats with ciprofibrate on liver microsomal UDPGT activities

\begin{tabular}{lcc}
\hline \multirow{2}{*}{ Substrate } & \multicolumn{2}{c}{ UDPGT activity* $^{*}$} \\
\cline { 2 - 3 } & Control & Ciprofibrate \\
\hline $\mathrm{T}_{4}$ & $1.61 \pm 0.19$ & $4.60 \pm 0.25 \ddagger$ \\
$\mathrm{T}_{3}$ & $0.35 \pm 0.05$ & $0.55 \pm 0.03 \ddagger$ \\
PNP & $25.6 \pm 2.4$ & $14.2 \pm 1.2 \ddagger$ \\
Androsterone $\dagger$ & $86 \pm 9$ & $67 \pm 2 \ddagger$ \\
\hline
\end{tabular}

* Expressed as pmol $\left(\mathrm{T}_{4}, \mathrm{~T}_{3}\right.$, androsterone) or nmol (PNP) per min per $\mathrm{mg}$ protein (mean $\pm \mathrm{SD}, \mathrm{N}=10$ ).

$\dagger$ Assayed using $10 \mu \mathrm{M}$ substrate and $0.5 \mathrm{mg}$ microsomal protein $/ \mathrm{mL}$.

$\ddagger$ Significantly different from controls $(\mathrm{P}<0.001)$.

microsomal androsterone UDPGT activity in Fischer rats is the same as that in Wistar LA microsomes. $\mathrm{T}_{4}$ is glucuronidated at roughly equal rates by liver microsomes from the different strains. However, $T_{3}$ glucuronidation shows a clear dichotomy with high activities in Wistar HA rats and low activities $(\approx 30 \%)$ in Wistar LA and Fischer rats.

Several conclusions can be drawn from the present and previous findings concerning the identity of the UDPGT isozymes involved with the conjugation of thyroid hormone. (1) With an androsterone UDPGT activity as low as that in the Wistar LA phenotype, Fischer rats appear to have a constitutive defect in this isozyme. (2) Normally, $T_{3}$ is glucuronidated mainly by androsterone UDPGT or by another isoenzyme with an identically transmitted genetic defect. However, $T_{3}$ is also conjugated to some extent by an UDPGT isozyme which is induced by ciprofibrate [this study]. Glucuronidation of $T_{4}$ is not impaired in Wistar LA and Fischer rats, suggesting that it is largely conjugated by other isozymes than androsterone UDPGT. (3) Hepatic $T_{4}$ glucuronidation is stimulated by both 3 -methylcholanthrene

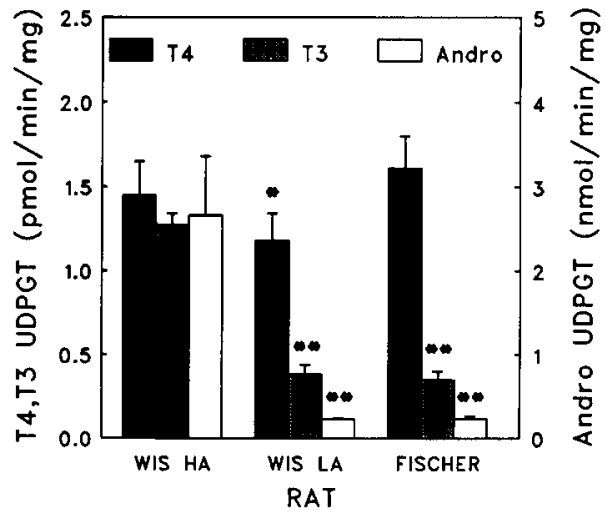

Fig. 1. UDPGT activities (mean $\pm \mathrm{SD}$ ) in liver microsomes from untreated Wistar HA $(N=8)$, Wistar LA $(N=4)$ and Fischer $(\mathrm{N}=10)$ rats. Androsterone UDPGT activity was assayed using $100 \mu \mathrm{M}$ substrate and $0.25 \mathrm{mg}$ microsomal protein $/ \mathrm{mL}$. * Significantly different from Wistar HA rats, $\mathrm{P}<0.05 ;{ }^{* *} \mathrm{P}<0.001$. 
(MC)-type microsomal enzyme inducers such as $\mathrm{MC}$ itself [16], polychlorobiphenyls (PCB) $[15,17]$, and $2,3,7,8-$ tetrachlorodibenzo- $p$-dioxin (TCDD) $[18,19]$, as well as by cipofibrate (this study). Studies with PCB and TCDD have shown that $T_{3}$ UDPGT activity is not increased $[15,18]$. A selective induction of the metabolic clearance of $T_{4}$ and not of $T_{3}$ has recently also been found with the fibrate nafenopin [8]. Clofibrate and other fibrates appear to be specific inducers of bilirubin UDPGT $[10,11]$. Therefore, these findings collectively suggest that $T_{4}$ is a substrate for both MC-inducible phenol UDPGT and clofibrate-inducible bilirubin UDPGT.

In conclusion, it has become clear that multiple UDPGT isozymes are involved with the glucuronidation of thyroid hormone. $T_{3}$ is perhaps primarily glucuronidated by androsterone UDPGT, whereas $T_{4}$ seems to be conjugated by both phenol and bilirubin UDPGT isozymes.

\section{* Department of Internal Medicine III and Clinical Endocrinology \\ Erasmus University Medical School \\ Rotterdam \\ The Netherlands \\ \$ Sterling-Winthrop Research Centre \\ Alnwick \\ Northumberland, U.K.}

\section{REFERENCES}

1. Ruegamer WR, Ryan NT, Richert DA and Westerfield WW, The effects of $p$-chlorophenoxyisobutyrate on the turnover rate and distribution of thyroid hormone in the rat. Biochem Pharmacol 18: 613-624, 1969.

2. McKerron CG, Scott RL, Asper SP and Levy RI, Effects of clofibrate (Atromid S) on the thyroxinebinding capacity of thyroxine-binding globulin and free thyroxine. J Clin Endocrinol 29: 957-961, 1969.

3. Lehotay DC, Paul HS, Adibi SA and Levey GS, Influence of clofibrate on thyroid hormone and muscle protein turnover. Metabolism 33: 1048-1051, 1984.

4. Visser TJ, Van Buuren JCJ, Rutgers M, Eelkman Rooda SJ and De Herder WW, The role of sulfation in thyroid hormone metabolism. Trends Endocrinol Metab 1: 211-218, 1990.

5. Osorio C, Walton KW, Browne CHW, West D and Whystock $\mathrm{P}$, The effect of $p$-chlorophenoxyisobutyrate ('Atromid S') on the biliary excretion and distribution of thyroxine in the rat. Biochem Pharmacol 14: 1479 1481,1965 .

$\dagger$ Address for correspondence: Theo J. Visser, $\mathrm{PhD}$, Department of Internal Medicine III, Erasmus University Medical School, P.O. Box 1738, 3000 DR Rotterdam, The Netherlands.
6. Harland WA and Orr JS, The effect of clofibrate on thyroxine metabolism. In: Thyroid Hormone Metabolism (Eds. Harland WA and Orr JS), pp. 6587. Academic Press, London, 1975.

7. Hinton RH, Mitchell FE, Mann A, Chescoe D, Price SC, Nunn A, Grasso P and Bridges JW, Effects of phthalic esters on the liver and thyroid. Environ Health Perspect 70: 195-210, 1986.

8. Kaiser CA, Seydoux J, Giacobino JP, Girardier L and Burger AG, Increased plasma clearance rate of thyroxine despite decreased 5'-monodeiodination: study with a peroxisome proliferator in the rat. Endocrinology 122: 1087-1093, 1988.

9. Astley N, Deavy L, Harpur ES, Bonner FW, Lockwood $G$ and Visser TJ, The effects of short term ciprofibrate administration on thyroid hormone metabolism in the male Fischer 344 rat. Human Exp Toxicol 10: 88-89, 1991.

10. Burchell $B$ and Coughtrie MWH, UDP-glucuronyltransferases. Pharmacol Ther 43: 261-289, 1989.

11. Boiteux-Antoine AF, Magdalou J, Fournel-Gigleux S and Siest G, Comparative induction of drugmetabolizing enzymes by hypolipidaemic drugs. Gen Pharmacol 20: 407-412, 1989.

12. Rutgers M, Pigmans IGAJ, Bonthuis F, Docter R and Visser TJ, Effects of propylthiouracil on the biliary clearance of thyroxine $\left(\mathrm{T}_{4}\right)$ in rats. Endocrinology 125: 2175-2186, 1989.

13. Bock KW, Fröhling W, Remmer $\mathbf{H}$ and Rexer B, Effects of phenobarbital and 3-methylcholanthrene on substrate specificity of rat liver microsomal UDPglucuronyltransferase. Biochim Biophys Acta 327: 46$56,1973$.

14. Matsui $M$ and Hakozaki $M$, Discontinuous variation in hepatic uridine diphosphate glucuronyltransferase toward androsterone in Wistar rats. Biochem Pharmacol 28: 411-415, 1979.

15. Beetstra JB, Van Engelen JGM, Karels P, Van der Hoek HJ, De Jong $M$, Docter $R$, Krenning EP, Hennemann G, Brouwer A and Visser TJ, Thyroxine and triiodothyronine are glucuronidated in rat liver by different UDP-glucuronyltransferases. Endocrinology 128: 741-746, 1991.

16. Bastomsky CH and Papapetrou PD, The effect of methylcholanthrene on biliary thyroxine excretion in normal and Gunn rats. J Endocrinol 56: 267-273, 1973.

17. Bastomsky $\mathrm{CH}$, Effects of a polychlorinated biphenyl mixture (Aroclor 1254) and DDT on biliary thyroxine excretion in rats. Endocrinology 95: 1150-1155, 1974.

18. Bastomsky $\mathrm{CH}$, Enhanced thyroxine metabolism and high uptake goiters in rats after a single dose of $2,3,7,8-$ tetrachlorodibenzo-p-dioxin. Endocrinology 101: 292296, 1977.

19. Henry EC and Gasiewicz TA, Changes in thyroid hormones and thyroxine glucuronidation in hamsters compared with rats following treatment with $2,3,7,8$ tetrachlorodibenzo-p-dioxin. Toxicol Appl Pharmacol 89: 165-174, 1987. 